\title{
Diversity and germination patterns of diatom resting stages at a coastal Mediterranean site
}

\author{
Marina Montresor*, Carmen Di Prisco, Diana Sarno, Francesca Margiotta, \\ Adriana Zingone
}

Stazione Zoologica Anton Dohrn, 80121 Naples, Italy

\begin{abstract}
Many planktonic diatoms produce resting stages that survive in the sediment and allow species persistence over periods in which vegetative growth does not occur. With the aim of depicting the annual variability of diatom benthic stage production and understanding the relationships between planktonic and benthic dynamics, we quantified diatoms in surface waters and their viable resting stages in surface sediments at the long-term ecological research station MareChiara (LTER-MC) in the Gulf of Naples (Mediterranean Sea) over 15 mo. A considerable fraction of the diatom species recorded in the water column was also obtained from germination in surface sediments, showing that the formation of resting stages is a widespread life strategy in coastal areas. The most abundant taxa recorded in the plankton were several species of the genera Chaetoceros, Skeletonema, Thalassiosira, Cyclotella, Pseudo-nitzschia and Bacteriastrum. Species of the latter 2 genera were never retrieved from the sediment. Peaks of viable resting stages were generally recorded in the same period as blooms of the individual species in the plankton. Repeated germination experiments with the same sediments demonstrated that some species are more resistant than others to prolonged darkness, while different daylength conditions did not produce a clear effect on germination patterns. This first time-series analysis of a coastal seed bank demonstrates that the assemblage of viable diatoms in the sediment varies over the year, reflecting the diatom dynamics in the water column, but also species-specific characteristics in survival capability and likely the disturbance due to biotic and abiotic factors.
\end{abstract}

KEY WORDS: Diatoms $\cdot$ Resting stages $\cdot$ Germination $\cdot$ Most probable number $\cdot$ MPN $\cdot$ Long-term ecological research station MareChiara $\cdot$ LTER-MC $\cdot$ Mediterranean Sea

Resale or republication not permitted without written consent of the publisher

\section{INTRODUCTION}

All phytoplankton species vary in their abundance over the seasons, and in many cases they are undetectable most of the time. The mechanisms regulating the wax and wane of species abundance and the role played by different life strategies are still unknown (Marcus \& Boero 1998). Some species may be in the water column all the time, at concentrations too low to be detected by routine sampling, i.e. operationally absent, and start growing at high rates under certain conditions. In other cases, vegetative growth at one place can be started by cells advected from elsewhere, or by the germination of resting stages from sediments or deep water column layers.

Resting stages are formed in several microalgal groups, including diatoms (Fryxell 1983, Round et al. 1990). In the latter, these stages comprise spores, which are morphologically different from vegetative cells, and resting cells that are apparently identical to vegetative cells (McQuoid \& Hobson 1996). Spores can be surrounded by an extremely thick siliceous frustule with various ornamentations, as in many Chaetoceros species (Ishii et al. 2011); in other cases, spore frustules broadly resemble those of vegetative cells, as in several Thalassiosira species (Syvertsen 1979). Like spores, resting cells have 
a number of features that are typical for stages that are meant to 'rest', i.e. to persist for a long time without undergoing cell division: a condensed cytoplasm, a high content of storage material, low photosynthetic rates, a high carbon:chlorophyll ratio and a low respiration rate (e.g. Anderson 1975, 1976, Hargraves \& French 1983, Kuwata et al. 1993). The cytological events occurring during resting spore formation have been investigated only in a few species, but it seems that the deposition of each new spore valve is associated with a mitotic division (Round et al. 1990). The only known exceptions are represented by Leptocylindrus danicus and Chaetoceros eibenii, in which the spore is produced inside the auxospore derived from gamete conjugation (von Stosch et al. 1973, French \& Hargraves 1985). Spores have been reported in several centric diatoms, but they are extremely rare in pennate species (McQuoid \& Hobson 1996).

Spores and resting cells play an important role in population dynamics of neritic diatoms (e.g. Garrison 1984, Smetacek 1985). The germination of spores stored in sediments was considered since the early beginnings of biological oceanography to be one factor responsible for seeding diatom-dominated spring blooms (Hensen 1887, Gran 1902). In several species, spore formation has been reported at the end of the bloom period (e.g. Pitcher 1986, Pitcher et al. 1991) and has been related to nitrogen depletion (e.g. Davis et al. 1980, Kuwata \& Takahashi 1990), which also seems to be a major trigger for spore formation in culture (McQuoid \& Hobson 1996). Spores and resting cells settle onto the sediments, where they can be stored alive for up to a century (Lewis et al. 1999, Härnström et al. 2011), and eventually inoculate the water column with vegetative cells upon germination and resumption of growth. There is no evidence that spores are dormant stages, i.e. with a mandatory period in which germination cannot occur: apparently, they can always resume vegetative growth when placed in suitable environmental conditions. Non-limiting nitrogen concentration $(\mathrm{Ku}-$ wata \& Takahashi 1999), appropriate combinations of temperature and daylength conditions (Eilertsen et al. 1995, McQuoid \& Hobson 1995), and underwater wavelength composition (Shikata et al. 2009, 2011) seem to control the switch from the resting to the growth phase, but spore germination has also been recorded in the absence of light (e.g. Jewson et al. 2008).

Diatom seed banks, mostly dominated by resting stages of neritic species belonging to the genera Chaetoceros, Skeletonema and Thalassiosira, have been reported mostly from coastal temperate and upwelling regions (e.g. Garrison 1981, Pitcher 1990, Itakura et al. 1997, McQuoid et al. 2002, McQuoid \& Godhe 2004). As for resting cells, which cannot be distinguished from vegetative cells, information on their presence, abundance and fate in the natural environment is rather elusive (Anderson 1975, but see Härnström et al. 2011). Evidence for their existence mostly comes from experiments aimed at testing the survival of cultures in the dark and at low temperatures (e.g. Smayda \& Mitchell-Innes 1974, Peters 1996a,b, Murphy \& Cowles 1997), which showed that several diatom species are capable of surviving in the absence of light for variable periods of time.

Diatoms play an important role in the warmtemperate coastal environment of the Gulf of Naples, where they constitute the dominant group during spring and autumn blooms, as well as during intense biomass peaks recorded during the water column stratification period, from late spring through summer (Zingone et al. 1990, 1995, 2010, Ribera d'Alcalà et al. 2004). Seasonal and interannual variations in the development of diatom blooms have been observed at the long-term ecological research station MareChiara (LTER-MC), where several spore- and resting-cell-forming species occur along with species known not to form such stages. Species responsible for biomass increases often present a well-defined, speciesspecific seasonal pattern, which recurs over the years despite a marked interannual variability for several environmental parameters (Ribera d'Alcalà et al. 2004).

Field studies on diatom resting stage production have so far been restricted to single date experiments or have addressed spatial variability, while the comparison with planktonic data has rarely been addressed. With the aim of depicting the annual variability of benthic stage production and understanding the relationships between planktonic and benthic stages, we studied diatom distribution in surface water and sediment samples at the LTER-MC station. Through ca. 100 germination experiments performed on 6 sediment samples collected between April 2007 and July 2008, we estimated the diversity and abundance of viable resting stages in relation to the dynamics of the corresponding planktonic stages in different periods of the year. Species-specific germination and viability patterns were assessed by repeating germination in the same sediments over time and under different daylengths. 


\section{MATERIALS AND METHODS}

The study was carried out at the LTER-MC, in the Gulf of Naples $\left(40^{\circ} 48.5^{\prime} \mathrm{N}, 14^{\circ} 15^{\prime} \mathrm{E}\right.$; Fig. 1), which has been sampled regularly for physical, chemical and biological parameters since 1984 (Ribera d'Alcalà et al. 2004). The sampling station is located 2 nautical miles offshore from the city of Naples, over a depth of $70 \mathrm{~m}$. Temperature, salinity and density profiles were obtained with a SBE911 CTD (Sea-Bird Electronics) mounted on a rosette sampler equipped with Niskin bottles. For the determination of total chlorophyll $a$, seawater samples were collected at 7 depths $(0.5,2,5,10,20,40$ and $60 \mathrm{~m})$ and filtered on Whatman glass-fibre filters (GF/F). Analyses were performed using a Shimadzu RF-5301 spectrofluorometer following Holm-Hansen et al. (1965). The concentration of inorganic nutrients was measured at 10 depths $(0.5,2,5,10,20,30,40,50,60$ and $70 \mathrm{~m})$, using a Systea Flowsys autoanalyzer (AxFlow) following Hansen \& Grasshoff (1983). Surface phytoplankton samples were collected weekly at $0.5 \mathrm{~m}$ depth using a Niskin bottle and were fixed with neutralised formaldehyde at a final concentration of $0.8 \%$. Depending on the richness of the samples, between 1 and $50 \mathrm{ml}$ were allowed to settle in combined sedimentation chambers, and cells were counted on 2 transects of the bottom plate with an inverted light microscope (Zeiss Axiovert) at 400x magnification (Utermöhl 1958). At least 200 cells of the most abundant species in the sample were enu-

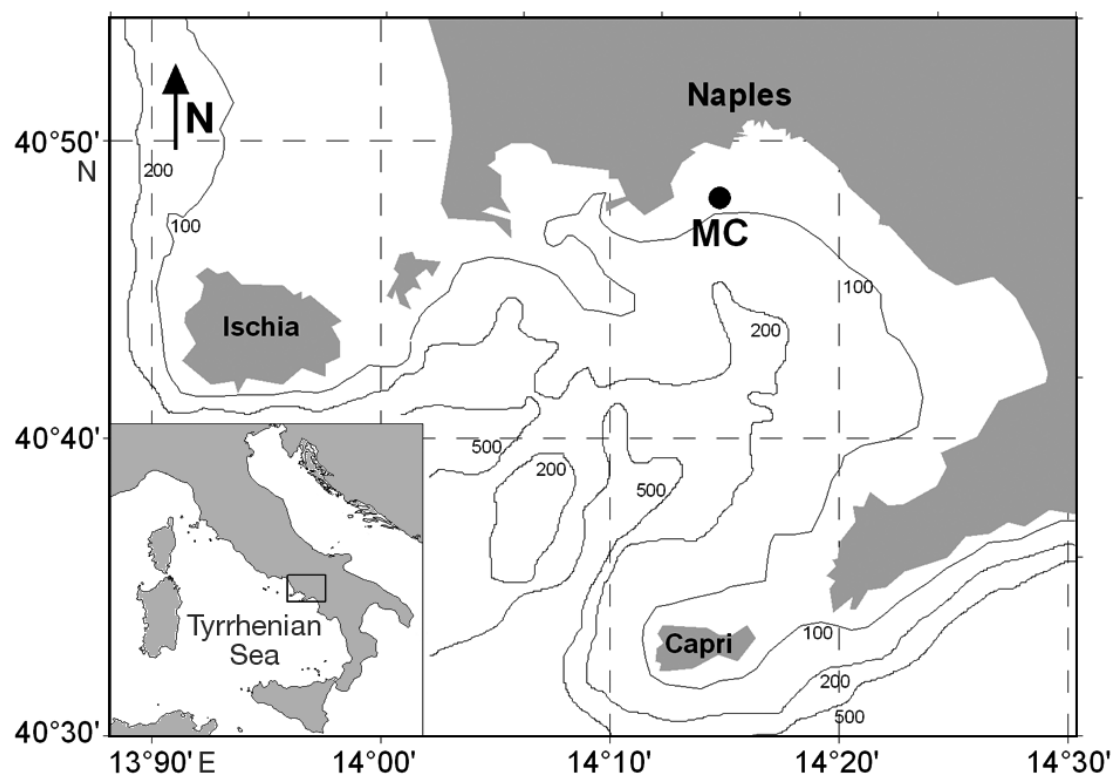

Fig. 1. Sampling area near the long-term ecological research station (LTER) MareChiara (MC) in the Gulf of Naples (Mediterranean Sea) merated. For the present study, 77 phytoplankton samples collected on a weekly basis - except in case of adverse meteorological conditions-between 4 January 2007 and 28 July 2008 were considered.

Surface sediment samples were collected approximately every 2 mo (Table 1 ) by means of a gravity corer equipped with 3 collectors of $4 \mathrm{~cm}$ in diameter. Core samples were kept in a cool box in the dark till processed (about $2 \mathrm{~h}$ ). Upon arrival at the laboratory, the surface portions $(1 \mathrm{~cm})$ of the 3 cores were collected, pooled together and gently mixed. Various subsamples of about $3 \mathrm{ml}$ were dispensed into Eppendorf vials, individually wrapped in aluminium foil and stored in a dark box at $10^{\circ} \mathrm{C}$. All sample processing steps were carried out at $14^{\circ} \mathrm{C}$ in dim light. Prior to the first germination experiment, samples were kept in dark, cool conditions for at least $3 \mathrm{wk}$, to ensure that only spores and/or resting cells were present in the sediments (Table 1), assuming that all recently settled vegetative cells would either die or transform into resting stages during this time interval. To investigate germination patterns and resting stage viability through time, incubations of subsamples from the same cores were repeated approximately every 2 mo (Table 1 ).

The abundance of resting stages was estimated using a modified version of the serial dilution culture method (SDC; Throndsen 1978, McQuoid 2002, McQuoid et al. 2002). The germination experiments were performed using 24-well tissue culture plates (Corning Life Sciences), having filled each well with $1800 \mu \mathrm{l}$ of $f / 4$ medium (50:50 v:v dilution of $f / 2$ medium; Guillard \& Ryther 1962). For each sediment sample, $1 \mathrm{~g}$ wet weight of sediment was transferred to a Falcon tube (Corning Life Sciences) and diluted with $f / 4$ medium to a final volume of $10 \mathrm{ml}$ (first dilution step 1:10). Of this material, $200 \mu l$, representing $1 / 500$ of the natural sample, was placed in each of the 6 wells of Row A after careful mixing of the tube's contents at each withdrawal. Six $200 \mu \mathrm{l}$ aliquots of material from the sixth well of Row A were used to inoculate the wells of Row B, thus obtaining a 1:10 dilution of the Row A sample. The procedure was repeated for Rows $C$ and $D$, to obtain 1:100 and 1:1000 dilutions of the Row A sample, respectively. Culture plates were sealed with parafilm and incubated in a culture chamber at 
$15^{\circ} \mathrm{C}$, at an irradiance of $5 \mu \mathrm{mol}$ photons $\mathrm{m}^{-2} \mathrm{~s}^{-1}$ for $1 \mathrm{wk}$. The plates were subsequently transferred to higher irradiance $\left(50 \mu \mathrm{mol}\right.$ photons $\left.\mathrm{m}^{-2} \mathrm{~s}^{-1}\right)$; the preexposure at low irradiance was aimed to simulate the gradual exposure to light of resting stages resuspended from surface sediments. Incubations started on the same day of fresh sediment samples and of those stored in dark and cold conditions since their collection (Table 1). For each sediment sample, 3 plates were prepared and incubated at $8 \mathrm{~h}: 16 \mathrm{~h}$; $12 \mathrm{~h}: 12 \mathrm{~h}$ and $16 \mathrm{~h}: 8 \mathrm{~h}$ light: dark to assess the impact of daylength on the germination success of diatom resting stages. The culture plates were inspected after $3 \mathrm{~d}$ of exposure at higher irradiance, and subsequently after 7, 14 and $21 \mathrm{~d}$. Plates were first ob-

Table 1. Sediment sampling dates at the long-term ecological research station MareChiara (LTER-MC), dates of serial dilution culture (SDC) incubations, and number of days between sediment collection and incubation experiments

\begin{tabular}{|c|c|c|}
\hline Sampling dates & SDC experiments & No. of days \\
\hline \multirow[t]{5}{*}{18 Apr 2007} & 10 May 2007 & 22 \\
\hline & 9 Jul 2007 & 82 \\
\hline & 26 Oct 2007 & 191 \\
\hline & 19 Dec 2007 & 245 \\
\hline & 28 Jan 2008 & 281 \\
\hline \multirow[t]{7}{*}{18 Jun 2007} & 9 Jul 2007 & 31 \\
\hline & 26 Oct 2007 & 130 \\
\hline & 19 Dec 2007 & 184 \\
\hline & 28 Jan 2008 & 224 \\
\hline & 21 Apr 2008 & 308 \\
\hline & 16 Jun 2008 & 364 \\
\hline & 25 Aug 2008 & 434 \\
\hline \multirow[t]{6}{*}{12 Sep 2007} & 26 Oct 2007 & 44 \\
\hline & 19 Dec 2007 & 98 \\
\hline & 28 Jan 2008 & 138 \\
\hline & 21 Apr 2008 & 222 \\
\hline & 16 Jun 2008 & 278 \\
\hline & 25 Aug 2008 & 345 \\
\hline \multirow[t]{5}{*}{20 Nov 2007} & 19 Dec 2007 & 29 \\
\hline & 28 Jan 2008 & 69 \\
\hline & 21 Apr 2008 & 153 \\
\hline & 16 Jun 2008 & 209 \\
\hline & 25 Aug 2008 & 279 \\
\hline \multirow[t]{4}{*}{8 Jan 2008} & 28 Jan 2008 & 20 \\
\hline & 21 Apr 2008 & 104 \\
\hline & 16 Jun 2008 & 160 \\
\hline & 25 Aug 2008 & 230 \\
\hline \multirow[t]{3}{*}{31 Mar 2008} & 21 Apr 2008 & 21 \\
\hline & 16 Jun 2008 & 77 \\
\hline & 25 Aug 2008 & 147 \\
\hline \multirow[t]{2}{*}{26 May 2008} & 16 Jun 2008 & 21 \\
\hline & 25 Aug 2008 & 91 \\
\hline 28 Jul 2008 & 25 Aug 2008 & 28 \\
\hline
\end{tabular}

served with an inverted microscope (Leica Microsystems) at 200× magnification for the record of larger and rarer species. The well content was then thoroughly mixed with a Pasteur pipette, and 2 drops were placed on a slide, which was observed with a Zeiss Axiophot microscope at 400× magnification, recording the presence of the species in each well. Cells were identified to the species level whenever possible using Rines \& Hargraves (1988), Hasle \& Syvertsen (1997) and the literature cited therein. The abundance of the individual species germinated in the experiments was assessed from their presence in the different dilution wells using the most probable number (MPN; Throndsen 1978) method. To this end, the most probable concentrations from the conversion tables reported by Throndsen (1978) were multiplied by 500 to account for the initial dilution of the sediment samples $(1 / 10 \times 1 / 50)$ prior to incubation in Row A of the culture plate.

To evaluate the effect of daylength on the germination success of diatom resting stages, 2-way ANOVA analysis was performed on the MPN values obtained for the most abundant species. Comparisons were carried out (1) amongst the data obtained from incubations of different samples taken within 1 mo of the sampling, (2) amongst the data obtained in successive incubations performed with the same sediment sample, and (3) amongst all incubations. For each species, the analysis was performed with both absolute density values (resting stages $\mathrm{g}^{-1}$ wet sediment) and values normalized over the total number of resting stages of that species in the different months/sediment samples under the 3 daylength conditions.

To explore the relationships between the abundance of viable resting stages and environmental parameters, a partial least-squares regression (PLS) was performed. The MPN abundance values were analyzed as dependent variables, and 25 environmental parameters were used as predictors. Temperature, salinity, seawater density, dissolved oxygen, nutrients $\left(\mathrm{PO}_{4}, \mathrm{NO}_{3}, \mathrm{NO}_{2}, \mathrm{NH}_{4}, \mathrm{DIN}\right.$ [dissolved inorganic nitrogen], $\mathrm{SiO}_{4}$ ) and chl a data were integrated over the surface layer ( 0 to $10 \mathrm{~m}$ ) and over the entire water column $(0$ to $70 \mathrm{~m})$; the differences between temperatures and densities at the surface and at depth $(70 \mathrm{~m}$ ) were also calculated, as an indication of water column stability. Daylength at the sampling site latitude was also included within the predictor variables. For the different parameters, values were averaged over 3 weeks preceding sediment sampling. PLS was performed using XLSTAT 2012 (Microsoft). 


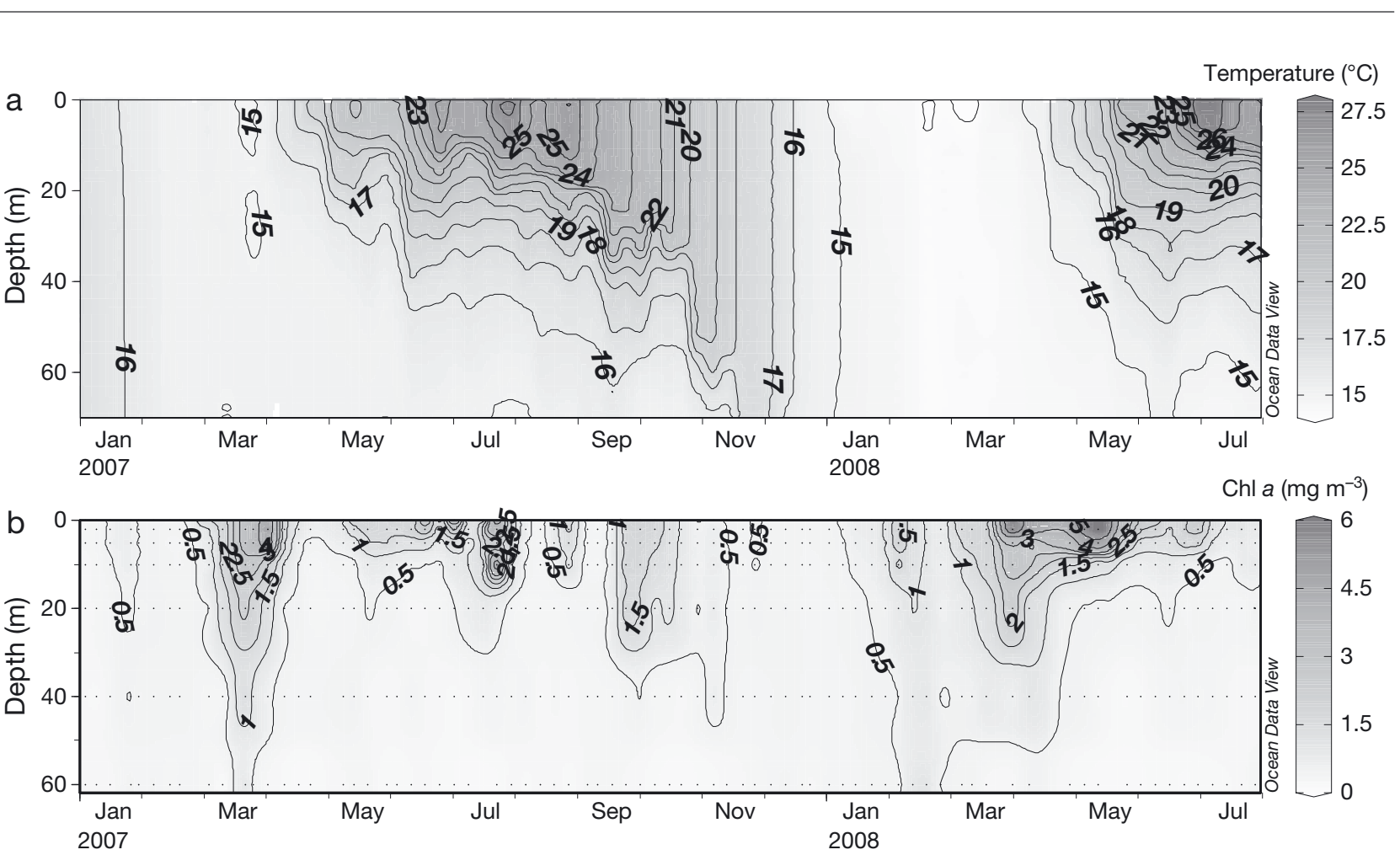

Fig. 2. Vertical distribution of (a) temperature $\left({ }^{\circ} \mathrm{C}\right)$ and (b) chlorophyll a $\left(\mathrm{mg} \mathrm{m}^{-3}\right)$ at LTER-MC from January 2007 to July 2008

\section{RESULTS}

\section{Environmental conditions}

Over the study period, temperatures varied between 13.46 and $28.12^{\circ} \mathrm{C}$ in surface waters and between 14.05 and $17.46^{\circ} \mathrm{C}$ in the bottom layer, at $70 \mathrm{~m}$ depth (Fig. 2a). The water column was homotherm down to the bottom from December until March, while thermal stratification started developing in April and disrupting in September (Fig. 2a). In both years, chlorophyll a (Fig. 2b) showed a first annual peak in late winter, with depth-averaged (60 m) values up to $2.13 \mathrm{mg} \mathrm{m}^{-3}$ (March 2007), and phytoplankton biomass was evenly distributed over most of the mixed water column. Other biomass peaks were recorded during late spring to summer of both years in the upper water column layer, with a maximum of $6.94 \mathrm{mg} \mathrm{m}^{-3}$ in May 2008. In late summer to autumn 2007, a secondary maximum (depthaveraged value: $1.26 \mathrm{mg} \mathrm{m}^{-3}$ ) developed upon the deepening of the pycnocline, while the annual minima $\left(\geq 0.22 \mathrm{mg} \mathrm{m}^{-3}\right)$ were measured during the winter months. Nutrient concentrations ranged between 0.08 and $9.73 \mathrm{mmol} \mathrm{m}^{-3}$ for DIN, 0.14 and $6.45 \mathrm{mmol}$ $\mathrm{m}^{-3}$ for silicates, and between undetectable $\left(\leq 0.01 \mathrm{mmol} \mathrm{m}^{-3}\right)$ and $0.26 \mathrm{mmol} \mathrm{m}^{-3}$ for orthophosphates (Table S1 in the Supplement at www.intres.com/articles/suppl/m484p079_supp.pdf).

\section{Diatom diversity in the water column and sediment}

From January 2007 to the end of July 2008, 90 diatom taxa were enumerated in surface plankton samples from LTER-MC; of these, 76 were identified to the species level and the remaining to the genus or group level (Table S2). Diatom cell concentrations in the plankton varied between 5.0 and $3.6 \times 10^{4}$ cells $\mathrm{ml}^{-1}$ (Fig. 3). Diatom abundance showed low values in January and February of both years, while its pattern slightly differed between the $2 \mathrm{yr}$ in the spring and summer periods. In 2007, cell numbers varied considerably over time, with alternating periods of high (max. $2.8 \times 10^{4}$ cells ml $^{-1}$ ) and low (min. 85 cells $\mathrm{ml}^{-1}$ ) abundances, while in 2008 they were constantly high (max. $3.6 \times 10^{4}$ cells $\mathrm{ml}^{-1}$ ) from mid-March throughout May. Skeletonema pseudocostatum, Leptocylindrus danicus, Chaetoceros socialis and $C$. tenuissimus were responsible for the major diatom peaks in both years, constituting up to $89.5 \%$ and averaging $31.9 \%$ of the total diatom population in terms of cell numbers.

Germination experiments produced vegetative stages of 41 diatom taxa, 39 of which were identified to the species or genus level (Table 2). The remainder were small centric diatoms belonging to different genera, e.g. Thalassiosira, Cyclotella, or Cymatosiraceae, and pennate diatoms mostly comprised of 


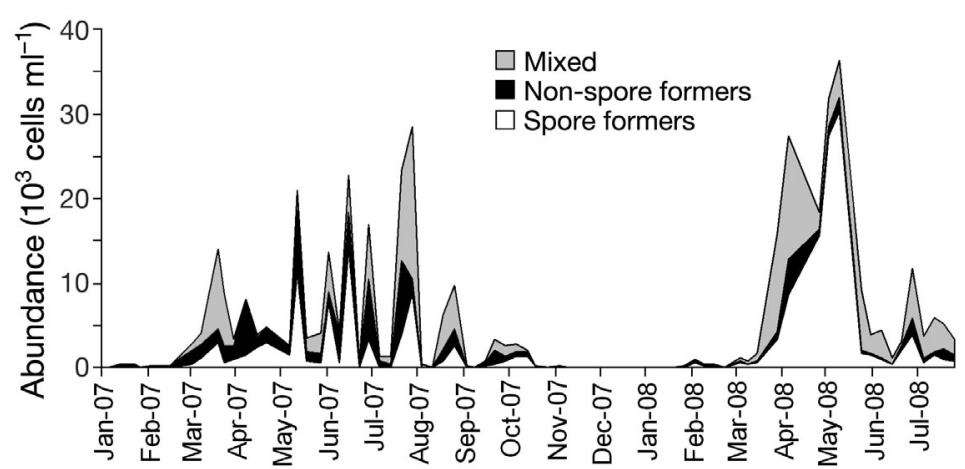

Fig. 3. Phytoplankton concentrations in surface waters at LTER-MC from January 2007 to July 2008. Species are grouped in 3 categories corresponding to those reported in Table S2: species recorded only in plankton samples (black: non-spore formers), species also recorded in the germinated sediments (white: spore formers), supra-specific taxa not identified at the species level, likely including both spore formers and species not forming resting stages (gray: mixed)

benthic species. With the exception of Chaetoceros tenuissimus, all the viable resting stages in the sediment belonged to species already known to form such stages from the literature, and mainly included Skeletonema pseudocostatum and various colonial Chaetoceros and small Thalassiosira species. The taxa germinated from the sediment also included such benthic species as Odontella aurita and Papiliocellulus simplex, rarely detected in the plankton. Based on comparison between the results of germination experiments and the abundances of planktonic cells, 3 groups of diatom species were recognized in water column samples: (1) species also detected in the germinated samples, (2) species only recorded in the plankton and (3) taxa not identified to the species level and hence not related to a specific resting stage (Fig. 3, Table S2). Of the 90 diatom taxa recorded in the plankton, 30 species were also recognized in the material germinated in the incubation experiments, indicating that these species produce either spores or resting cells, while 44 species were recorded only in the plankton, thus suggesting that they do not form benthic resting stages. Among them, all Bacteriastrum and Pseudo-nitzschia species, Cerataulina pelagica and the small and solitary Chaetoceros minimus were found. The third category of supra-specific taxa included Chaetoceros spp., Thalassiosira spp. and pennate and centric diatoms. Most probably, many undetermined centric taxa produced resting stages, since small-sized, undetermined centric diatoms were also abundant in the germinated sediment samples.

A considerable temporal variability in resting stage quantity and composition emerged from the germination experiments carried out within 1 mo of sediment collection. The total MPN abundance ranged from $5.8 \times 10^{3}$ to $1.0 \times 10^{5}$ cells $\mathrm{g}^{-1}$ wet sediment, with a minimum in January 2008 and a maximum in June 2007 (Fig. 4). The PLS regression results were statistically significant $\left(Q_{2}>0.0975\right)$, and the 2-dimension model explained $90 \%$ of the variance of the diatom resting stages (dependent variable) and $72 \%$ of the environmental parameters (predictors; Table 3). The main environmental variables that were related to the abundance of resting stages (variable importance in the projection [VIP] > 1) were nitrogen and silicate availability (water-column-integrated $\mathrm{NO}_{3}$ and DIN values, surface and integrated $\mathrm{SiO}_{4}$ values), salinity and daylength (Table 4). The coefficients obtained from the models were all negative, except for day length.

Between 14 and 23 distinct diatom taxa grew in each germination experiment. Skeletonema pseudocostatum markedly dominated the sediment samples in June and September 2007 and in May 2008, constituting up to $92 \%$ of the total diatom assemblage in June 2007. Chaetoceros socialis and small centric diatoms always constituted a significant fraction of the resting stage assemblage (Fig. 4).

\section{Viable resting stages versus vegetative cells}

The abundance of vegetative cells in surface water samples and of viable resting stages in sediment is represented in Fig. 5 for Skeletonema pseudocostatum, Leptocylindrus danicus and a number of Chaetoceros species. The most abundant species in the incubated sediment samples $-S$. pseudocostatum and C. socialis - were also abundant in the water column (Fig. 5). S. pseudocostatum reached the highest cell concentrations in the plankton in spring to early summer of both years, and showed low resting stage abundance in April 2007, followed by high values in sediment collected in summer and a decrease in winter, when the species was not detected in the plankton. Resting stages were abundant again after the vegetative cell peak of May 2008. The temporal match between vegetative cells and viable resting stages was not always evident for $C$. socialis; high concentrations of resting stages were recorded in the same period as peaks of vegetative cells (March and May 2008) or after them (April and September 2007), but the high number of spores recorded in November 2007 did not correspond to any vegetative cell peak in the same period or before. L. danicus and C. tenu- 
Table 2. Diatom species and supra-specific taxa germinated from all sediment incubation experiments ranked in order of their average abundance (cells $\mathrm{g}^{-1}$ wet sediment)

\begin{tabular}{lr|}
\hline Taxon & Avg. abundance \\
\hline Skeletonema pseudocostatum & 8650.23 \\
Undetermined centric diatoms & 4312.82 \\
Chaetoceros socialis & 3774.40 \\
Chaetoceros diadema & 943.33 \\
Chaetoceros curvisetus & 730.23 \\
Thalassiosira cf. allenii & 577.50 \\
Chaetoceros protuberans & 286.81 \\
Leptocylindrus danicus & 244.72 \\
Odontella aurita & 217.36 \\
Skeletonema menzelii & 189.07 \\
Undetermined pennate diatoms & 118.43 \\
Thalassiosira spp. & 76.76 \\
Chaetoceros sp. 1 (colonial) & 74.86 \\
Cylindrotheca closterium & 69.86 \\
Chaetoceros tenuissimus & 69.07 \\
Papiliocellulus simplex & 56.81 \\
Chaetoceros cf. wighamii & 52.31 \\
Asterionellopsis glacialis & 45.88 \\
Lithodesmium cf. undulatum & 42.69 \\
Skeletonema cf. dohrnii & 37.50 \\
Skeletonema tropicum & 31.85 \\
Chaetoceros simplex & 25.69 \\
Chaetoceros costatus & 16.94 \\
Thalassiosira rotula & 16.25 \\
Chaetoceros contortus & 14.86 \\
Biddulphia alternans & 12.50 \\
Chaetoceros cf. constrictus & 12.13 \\
Odoetoceros affinis & 11.62 \\
Chaetoceros decipiens & 9.17 \\
Chaetoceros cf. simplex & 6.62 \\
Chaetoceros sp. 2 (single) & 5.56 \\
Ditylum brightwellii & 4.54 \\
Undetermined Cymatosiraceae & 4.54 \\
Minutocellulus cf. polymorphus & 3.84 \\
Thalassionema nitzschioides & 3.52 \\
Arcocellulus sp. & 1.85 \\
Asterionella cf. kariana & 1.67 \\
Chaetoceros lauderi & 0.93 \\
Thalassiosira mediterranea & 0.93 \\
& 0.93 \\
& \\
\hline
\end{tabular}

issimus showed marked density peaks in the water column during late spring and summer, and resting stages peaked in the sediment in the same period, while they were negligible or absent in winter and spring samples. However, resting stage abundance was low as compared to vegetative cell abundance for these species, especially for C. tenuissimus, which was recorded only twice in germination experiments. C. curvisetus (Fig. 5) was present in the plankton over a broad time interval, spanning from early spring to summer. Accordingly, viable resting stages were recorded on all sampling dates in relatively

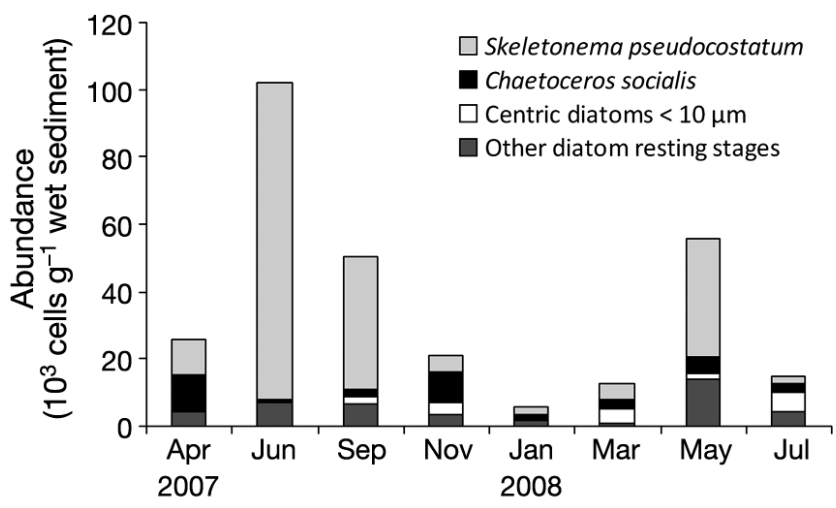

Fig. 4. Most probable number (MPN) of viable diatom resting stage cells ( $\mathrm{g}^{-1}$ wet sediment) recorded at LTERMC between April 2007 and July 2008

Table 3. Cumulative quality indices for the partial leastsquares (PLS) regression of the most probable number of resting stages per gram of wet sediment $(Y)$ and environmental variables $(X)$. Cum: cumulative fraction of the explained or predicted variation; $Q^{2}$ : predicted fraction of the variation in $Y_{i} R_{Y}^{2}$ : variance explained for dependent variables; $R_{X}^{2}$ : variance explained for predictor $(Y)$ variables. PLS is significant when $Q^{2}>0.0975$

\begin{tabular}{|lcc|}
\hline Index & Component1 & Component2 \\
\hline$Q^{2}$ cum & 0.201 & 0.673 \\
$R^{2}{ }_{Y}$ cum & 0.572 & 0.904 \\
$R^{2}$ cum & 0.421 & 0.722 \\
\hline
\end{tabular}

Table 4. Variable importance in the projection (VIP) and normalized coefficients for the most important environmental predictors influencing the abundance of viable diatom resting stages. DIN: dissolved inorganic nitrogen

\begin{tabular}{|lccr|}
\hline Variable & $\begin{array}{c}\text { VIP } \\
\text { (Component1) }\end{array}$ & $\begin{array}{c}\text { VIP } \\
\text { (Component2) }\end{array}$ & $\begin{array}{c}\text { Norm. } \\
\text { coeff. }\end{array}$ \\
\hline $\mathrm{NO}_{3}(0-70 \mathrm{~m})$ & 2.123 & 1.716 & -0.223 \\
Salinity $(0-10 \mathrm{~m})$ & 1.505 & 1.609 & -0.219 \\
Salinity (0-70 m) & 1.624 & 1.507 & -0.209 \\
$\mathrm{SiO}_{4}(0-10 \mathrm{~m})$ & 1.480 & 1.183 & -0.131 \\
$\mathrm{SiO}_{4}(0-70 \mathrm{~m})$ & 1.111 & 1.349 & -0.178 \\
Day length & 1.290 & 1.069 & 0.143 \\
DIN (0-70 m) & 1.211 & 1.017 & -0.058 \\
\hline
\end{tabular}

high numbers. C. contortus, C. diadema and C. protuberans (Fig. 5) were found in the water column in spring, with peak abundances in 2008 ; this trend was reflected by the abundance of resting stages in the sediment, which also peaked in spring to summer 2008. Finally, a correspondence between the timing of vegetative cells in the water column and the resting stages in the sediment was also evident for 


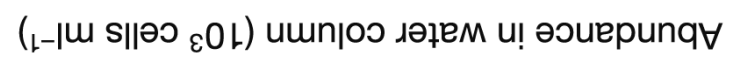

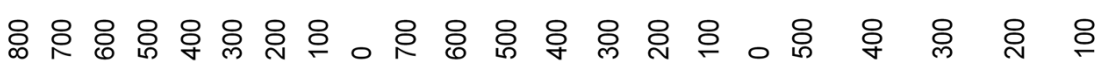
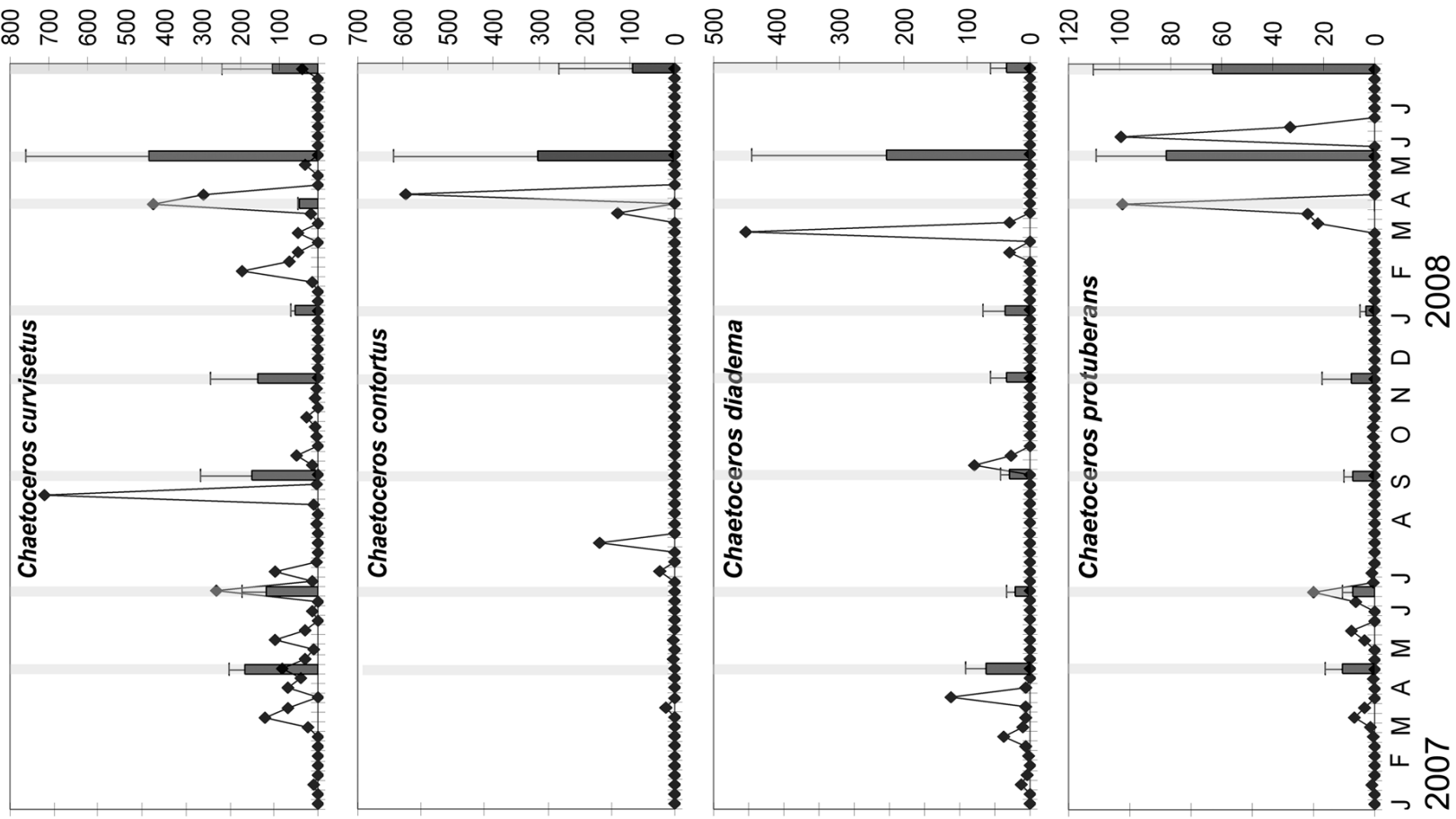

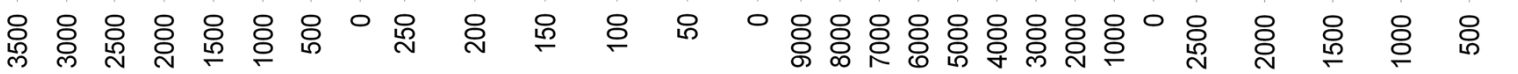

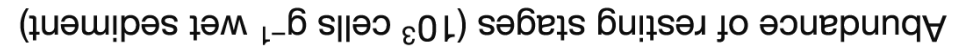

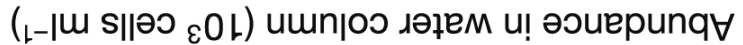

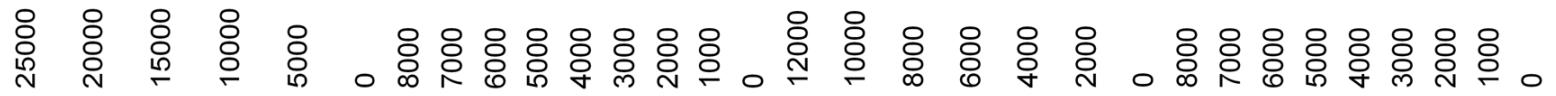
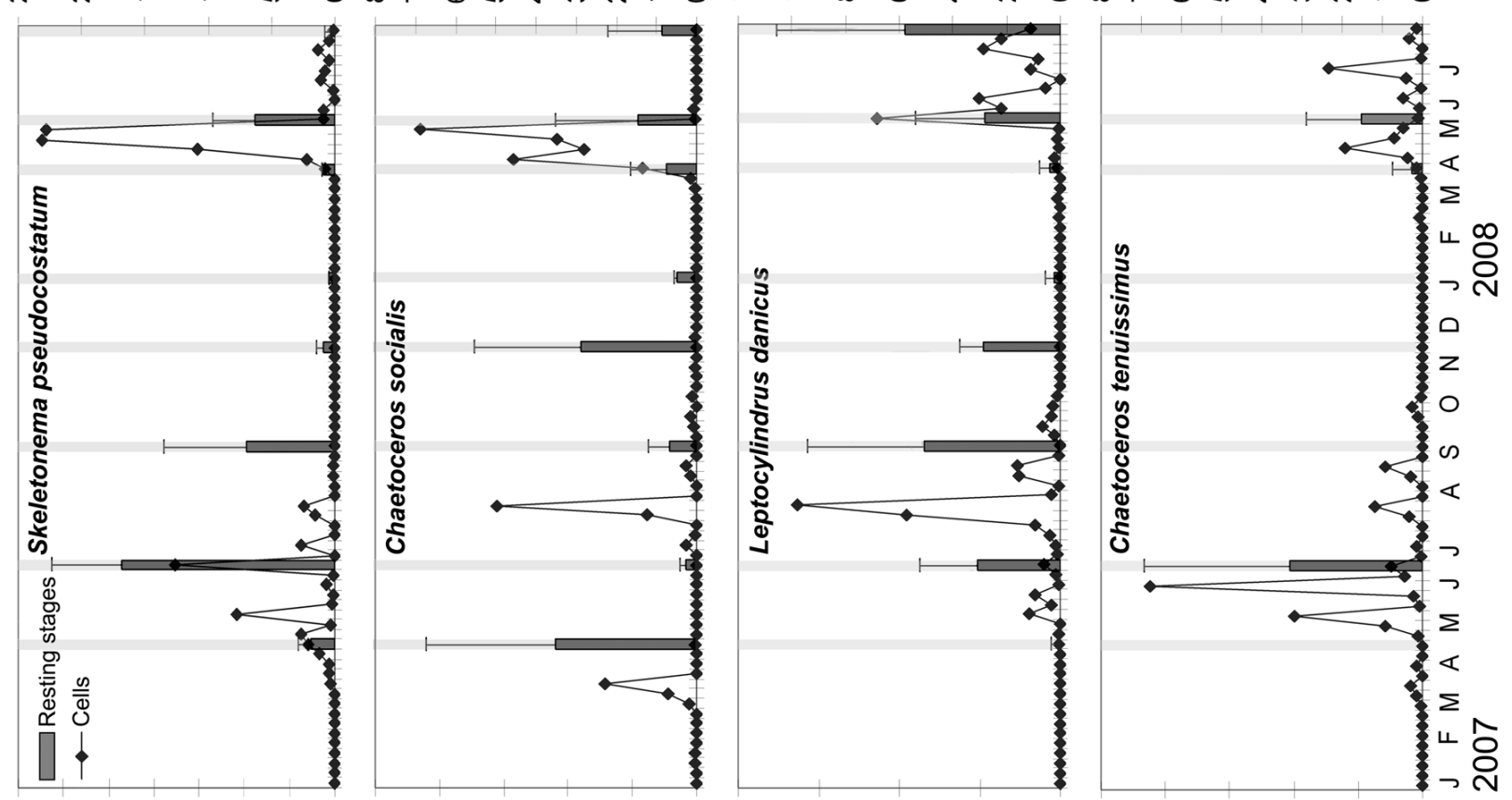

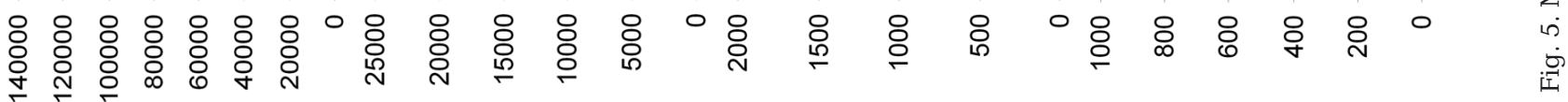

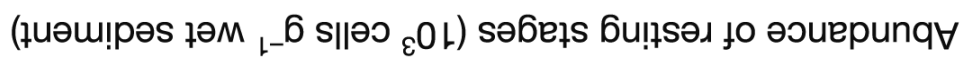




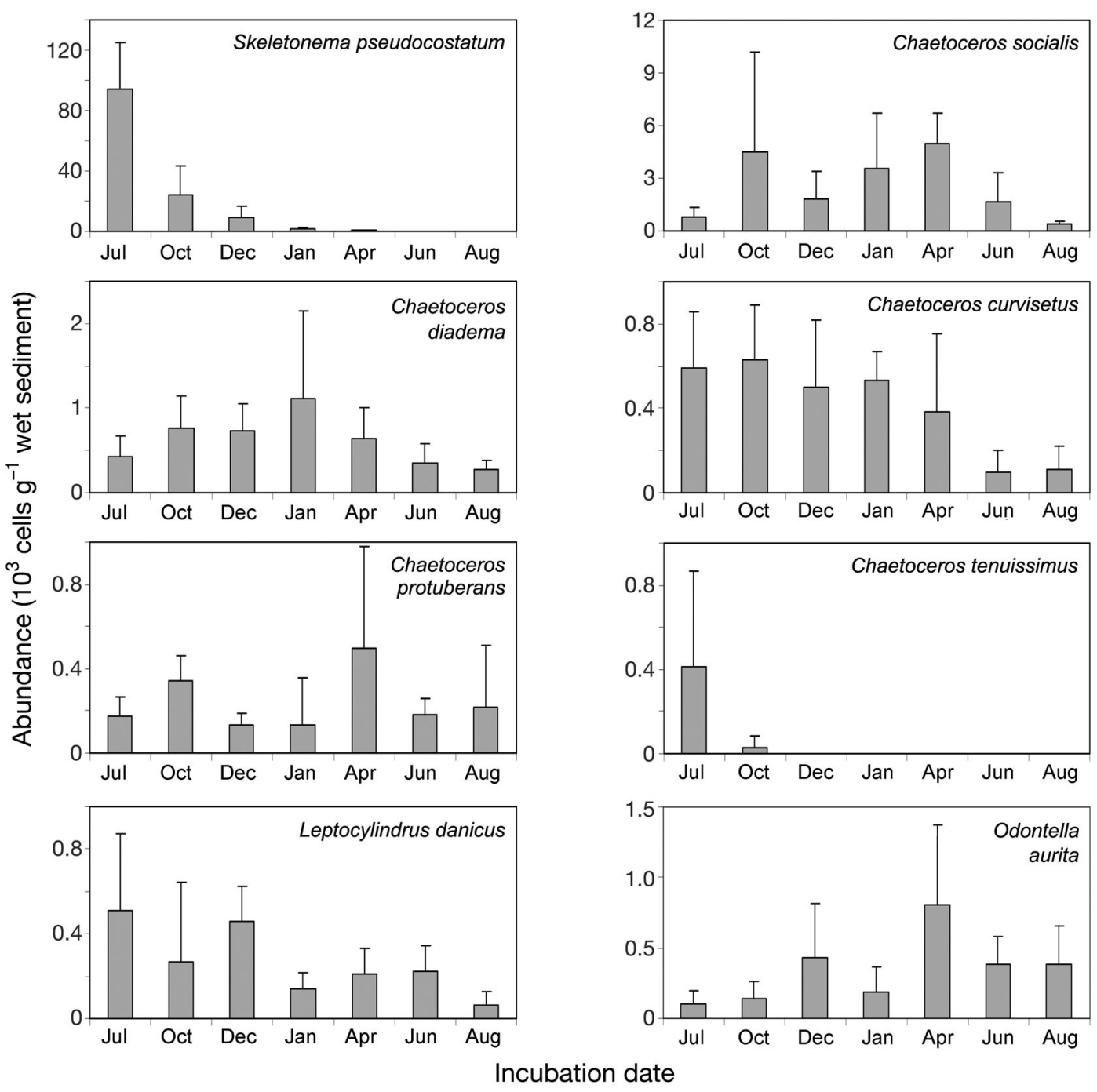

Fig. 6. Most probable number (MPN) of viable diatom resting stages ( $\mathrm{g}^{-1}$ wet sediment; mean and $\mathrm{SD}$ of 3 incubations) recorded in repeated incubations of the sediment sample collected in June 2007

S. menzelii, which reached the highest concentrations in summer to early autumn plankton, and showed a resting stage peak in September 2007. In contrast, the summer bloom of $S$. tropicum did not correspond to any peaks of resting stages in the sediment (Table 5, Fig. S1 in the Supplement at www. int-res.com/articles/suppl/m482p079_supp.pdf).

\section{Germination patterns and resting stage viability}

The effect of daylength on germination success was tested under 3 conditions: 8,12 and $16 \mathrm{~h}$ of light. The estimated number of viable resting stages showed variations amongst the different treatments, but no consistent pattern was detected. The number of viable resting stages obtained under the 3 experimental conditions for the 6 most abundant species (Skeletonema pseudocostatum, Chaetoceros socialis, C. diadema, C. curvisetus, C. protuberans and Leptocylindrus danicus) showed no significant differences (ANOVA, $\mathrm{p}>0.05$ ) amongst the treatments.

Resting stage viability over time and seasonality in germination responses was evaluated by repeating experiments with each sediment sample in the months following its collection, resulting in up to 7 experiments over $>1 \mathrm{yr}$ for the sample collected in June 2007 (Table 1). The results of these experiments are illustrated in Fig. 6 for the sediment samples collected in June 2007, and for the most abundant species therein. The results obtained with repeated experiments with the complete set of sediment samples 
are illustrated in Fig. S1. Due to the lack of clear differences, results obtained under different daylength conditions were averaged in this analysis. Several species were recovered in all germination experiments performed with the same sediment over time (Fig. 6, Fig. S1). By contrast, resting stages of some species, including Chaetoceros tenuissimus (Fig. 6) Cylindrotheca closterium and Skeletonema menzelii (Fig. S1), showed limited viability, being recorded only in one or a few experiments following the one performed shortly after collection. Resting stages of $S$. pseudocostatum showed a variable pattern. When the species was abundant in the sediment, i.e. in the summer samples of 2007 (Fig. 6) and in the latespring sample of 2008 (Fig. S1), corresponding to maximum abundance in the plankton, a marked decrease in viability for the same sediment was observed over time; in the case of sediment collected in other periods of the year, i.e. when the species was far less abundant or not detected at all in the plankton, similar viable cell values were recorded over time (Fig. S1). Resting stages of Chaetoceros curvisetus, $C$. diadema, C. protuberans and C. socialis germinated with similar success over several months, while Leptocylindrus danicus showed a slight decrease. Rather constant germination was also detected for the 2 centric benthic diatoms Odontella aurita and Papiliocellulus simplex (Fig. 6, Fig. S1). In a few cases, the maximum yield for a species was not obtained in the first incubation experiment but rather in the incubations performed several months after the sample collection. However, this pattern was never consistent enough to indicate dormancy and/or seasonality in the germination pattern of the species.

\section{DISCUSSION}

Results of the germination experiments performed with sediment collected at different times of the year allowed us to clarify some aspects of the relationships between benthic and pelagic stages of diatoms in the study area. Rather than a mere repository of species seeds, the assemblage of viable stages in the sediment was variable, which reflects the dynamics of the diatom blooms in the upper layers, but is also subject to independent dynamics, in relation to species-specific characteristics in survival capability, spatial heterogeneity of the environment and disturbance from biotic and abiotic factors. The diversity of viable resting stages in the sediment is lower than that of diatoms in the water column, but almost all of the most abundant species in surface waters were also recorded as resting stages in the sediment, which confirms the relevance of this life strategy in coastal diatoms. The most abundant diatom taxa recorded in both plankton and sediments belong to the genera Chaetoceros, Skeletonema and Thalassiosira, while Pseudo-nitzschia and Bacteriastrum species were abundant in the water column but were never obtained from germination experiments. No significant differences in germination success were recorded among the 3 daylength conditions tested (8, 12 and $16 \mathrm{~h}$ of light), suggesting that daylength does not play a role in the germination in diatom species from the area.

\section{Diversity of resting stages}

The highest diatom species diversity in both plankton and benthic stages from the Gulf of Naples was shown by species of the genus Chaetoceros. Among them, large, colony-forming species (e.g. C. contortus and C. protuberans) contribute to the late winter to early spring blooms in the Gulf of Naples, while $C$. socialis generally has a bimodal occurrence pattern, with peaks in April and November, and the singlecelled C. tenuissimus and C. simplex become abundant during the summer period (Table 5; Ribera d'Alcalà et al. 2004). Several Chaetoceros species (C. socialis, C. diadema, C. curvisetus and C. protuberans) were also represented in surface sediment with high numbers of viable resting stages, thus confirming the relevance of the resting strategy to the persistence of those species between bloom periods. However, other species, such as $C$. tenuissimus, $C$. minimus and C. contortus, which reached high concentrations in the water column, were seldom detected in the germinated samples, indicating that high numbers of benthic resting stages do not necessarily characterize all species of this genus. Similar interspecific life-strategy differences were noticed by Mc Quoid \& Godhe (2004), who followed the temporal development of diatom assemblages in microcosms started with different inocula - phytoplankton samples, sediment samples and a mixture of both. Their results showed that some species, e.g. C. Compressus, C. lauderi and C. lorenzianum, relied mostly on planktonic inocula, while for others, e.g. C. debilis and C. curvisetus, the contribution of benthic stages was much more relevant.

Four Skeletonema species - S. pseudocostatum, $S$. menzelii, S. tropicum and $S$. dohrnii-were obtained from the incubations of sediment, of which S. pseudocostatum was by far the most abundant resting 
Table 5. Cell density and temporal patterns at the LTER-MC station of the most abundant diatom species forming resting stages: average concentration (cells ml ${ }^{-1}, \pm \mathrm{SD}$ ), months in which the species recorded with cell concentrations higher than the average value of the period (plankton occurrence), date on which the maximum cell concentration was recorded in the plankton (plankton maximum), month in which the maximum concentration of viable resting stages was recorded in the sediments incubated after collection (sediment maximum), maximum viability expressed as the number of days of storage in cold and dark conditions after which viable resting stages were recorded in germination experiments (max. viability); nr: species not recorded in the first germination experiment

\begin{tabular}{|c|c|c|c|c|c|}
\hline Species & Cells $\left(\mathrm{ml}^{-1}\right)$ & Plankton occurrence & $\begin{array}{l}\text { Plankton } \\
\text { maximum }\end{array}$ & $\begin{array}{l}\text { Sediment } \\
\text { maximum }\end{array}$ & $\begin{array}{c}\text { Max. } \\
\text { viability (d) }\end{array}$ \\
\hline Skeletonema pseudocostatum & $1320 \pm 4133$ & $\begin{array}{l}\text { Apr-Jul 2007; } \\
\text { Apr-May } 2008\end{array}$ & 8 May 2008 & Jun 2007 & 308 \\
\hline Leptocylindrus danicus & $613 \pm 1568$ & $\begin{array}{l}\text { May, Jul-Sep 2007; } \\
\text { May-Jul } 2008\end{array}$ & 31 Jul 2007 & Jul 2008 & 434 \\
\hline Chaetoceros socialis & $390 \pm 1207$ & $\begin{array}{l}\text { Mar, Jul 2007; } \\
\text { Apr-May } 2008\end{array}$ & 13 May 2008 & Apr 2007 & 434 \\
\hline Chaetoceros tenuissimus & $314 \pm 914$ & $\begin{array}{l}\text { May-Aug 2007; } \\
\text { Apr-Jul } 2008\end{array}$ & 5 Jun 2007 & Jun 2007 & 245 \\
\hline Chaetoceros curvisetus & $40 \pm 105$ & $\begin{array}{l}\text { Mar-Sep 2007; } \\
\text { Feb-Apr } 2008\end{array}$ & 28 Aug 2007 & May 2008 & 434 \\
\hline Cylindrotheca closterium & $38 \pm 75$ & $\begin{array}{l}\text { Apr-Aug, Oct 2007; } \\
\text { Apr-Jul } 2008\end{array}$ & 22 May 2007 & July 2008 & 91 \\
\hline Skeletonema menzelii & $27 \pm 90$ & $\begin{array}{l}\text { Jul-Oct 2007; } \\
\text { Jul } 2008\end{array}$ & 9 Oct 2007 & Sep 2007 & 191 \\
\hline Skeletonema tropicum & $17 \pm 119$ & Sep-Oct 2007 & 16 Oct 2007 & May 2008 & 160 \\
\hline Chaetoceros simplex & $14 \pm 47$ & $\begin{array}{l}\text { May-Aug 2007; } \\
\text { Jun-Jul } 2008\end{array}$ & 24 Jun 2008 & Nov 2007 & 209 \\
\hline Minutocellus cf. polymorphus & $14 \pm 55$ & $\begin{array}{l}\text { Jul 2007; } \\
\text { May-Jul } 2008\end{array}$ & 3 Jun 2008 & $\mathrm{nr}$ & 364 \\
\hline Chaetoceros contortus & $12 \pm 71$ & $\begin{array}{l}\text { Mar, Jul 2007; } \\
\text { Mar-Apr } 2008\end{array}$ & 9 Apr 2008 & May 2008 & 308 \\
\hline Chaetoceros diadema & $11 \pm 54$ & $\begin{array}{l}\text { Jan-Mar, Sep 2007; } \\
\text { Feb-Mar } 2008\end{array}$ & 7 Mar 2008 & May 2008 & 434 \\
\hline Chaetoceros affinis & $10 \pm 34$ & $\begin{array}{l}\text { Mar, Sep 2007; } \\
\text { Feb-Apr, Jul } 2008\end{array}$ & $1 \mathrm{Jul} 2008$ & Sep 2007 & 281 \\
\hline Thalassionema nitzschioides & $10 \pm 32$ & $\begin{array}{l}\text { May-Jul, Oct 2007; } \\
\text { Jul } 2008\end{array}$ & 19 Jun 2007 & Jan 2008 & $31^{\mathrm{a}}$ \\
\hline Asterionellopsis glacialis & $7 \pm 38$ & $\begin{array}{l}\text { Mar 2007; } \\
\text { Feb, Apr } 2008\end{array}$ & 1 Apr 2008 & May 2008 & 160 \\
\hline Thalassiosira mediterranea & $7 \pm 40$ & $\begin{array}{l}\text { Jan 2007; } \\
\text { Jan-Feb, Apr, Jun } 2008\end{array}$ & 9 Apr 2008 & $\mathrm{nr}$ & $82^{\mathrm{a}}$ \\
\hline Thalassiosira rotula & $6 \pm 28$ & $\begin{array}{l}\text { May, Sep-Nov 2007; } \\
\text { Feb, May } 2008\end{array}$ & 9 Oct 2007 & May 2008 & 209 \\
\hline Chaetoceros protuberans & $4 \pm 17$ & $\begin{array}{l}\text { May-Jun 2007; } \\
\text { Mar-Apr, Jun } 2008\end{array}$ & 10 Jun 2008 & May 2008 & 434 \\
\hline Chaetoceros cf. wighamii & $4 \pm 25$ & $\begin{array}{l}\text { Apr 2007; } \\
\text { Feb-Apr } 2008\end{array}$ & 9 Apr 2008 & Jun 2007 & 434 \\
\hline
\end{tabular}

stage. This species is among the most abundant diatoms in the Gulf of Naples, with recurrent blooms in late spring and early summer (Table 5; Ribera d'Alcalà et al. 2004). The dominance of Skeletonema in the plankton and its capability to produce extremely high numbers of benthic resting stages in the sediment have been reported in studies carried out at various latitudes (e.g. Itakura et al. 1997, McQuoid et al. 2002, Ishikawa \& Furuya 2004, Chen et al. 2009, Shikata et al. 2009). This feature, along with the capability of Skeletonema resting stages to survive for a long time in anoxic conditions (Härnström et al. 2011), enables a strong benthic-pelagic coupling and contributes to explaining the high abundance and recurrent blooms of these species at several coastal sites (e.g. Ribera d'Alcalà et al. 2004, Thompson et al. 2008, Borkman \& Smayda 2009).

Resting stages of Leptocylindrus danicus were regularly detected in sediment samples, but their numbers were remarkably low as compared to the high concentrations in the water column recorded in summer (Table 5). Recent studies have shown that the 
name $L$. danicus has been used so far for at least 4 distinct taxa, including the nominal species $L$. danicus-producing spores after the sexual phase (French \& Hargraves 1985), the variety L. danicus var. apora that does not produce spores (French \& Hargraves 1986) and 2 other undescribed species, 1 of which also produces spores (Nanjappa et al. 2012). Hence, the relatively low number of resting stages recorded in this study might be explained either by the low frequency of sexual events that precede the formation of spores in L. danicus and/or the numerical dominance of Leptocylindrus species or varieties that do not form resting spores at all. This might also be the reason why L. danicus, while relatively abundant in the plankton, did not show high abundances of resting stages in the sediments collected in a Swedish fjord, and was mostly recorded in microcosms inoculated with phytoplankton samples (McQuoid \& Godhe 2004).

A considerable fraction of the diatoms that germinated from surface sediments of the Gulf of Naples was constituted by small-sized Thalassiosira-like cells. Such small centric diatoms were also abundant in the plankton, but could not be identified more precisely.

Species of the genera Pseudo-nitzschia and Bacteriastrum did not germinate in any incubation experiments. Their abundance in the plankton of the area was high, implying that at least some cells should have settled onto the surface sediments. The lack of records of viable resting stages of Bacteriastrum might be explained by the fact that the most abundant species of the genus in the Gulf of Naples is $B$. parallelum, which is not known to form spores (McQuoid \& Hobson 1996). Viable resting stages of Pseudo-nitzschia species have never been reported in sediments or in laboratory studies, with the only exception a record from the eastern coast of Russia (reported by Lelong et al. 2012). The apparent lack of a benthic resting strategy in these diatoms is also supported by the results of McQuoid \& Godhe (2004), who detected the development of Pseudo-nitzschia spp. blooms in mesocosms inoculated with plankton samples, but never in those inoculated with surface sediments. These pennate diatoms are apparently incapable of surviving in the benthic environment and probably 'rest' somewhere else. Cylindrotheca closterium, Thalassionema nitzschioides and Asterionellopsis glacialis are other planktonic pennate diatoms that were recorded at times in germination experiments, albeit with relatively short survival times, indicating that these species may survive in the sediment for some time.

\section{MPN method}

The small size of diatom vegetative cells and resting stages represents a severe hindrance to their direct detection and quantification in the sediment. In this respect, the serial dilution method coupled with the MPN abundance estimation (Imai et al. 1984, McQuoid 2002, McQuoid et al. 2002) is one way to overcome these problems. However, this method only provides a minimum estimate of the diversity and abundance of viable resting stages. Several conditions must be satisfied in order to record a species in SDCs. First, resting stages must be able to germinate in the medium used and under the selected experimental conditions (temperature, irradiance, daylength), and cells produced must be able to grow therein. Further, competition may occur in the multi-specific cultures obtained from sediment germination, related to species-specific differences in growth rates and/or to the production of chemical compounds that might inhibit or favour the growth of certain species (e.g. Paul et al. 2009). Germination failures and/or the incapability to grow at the experimental conditions result in underestimation of the diversity and abundance of the taxa originally present in the sediment sample used in the SDC incubations. Moreover, the SDC method does not allow detection of the least abundant species, in our case those that were present at concentrations around or $<100$ viable resting stages $\mathrm{g}^{-1}$ of wet sediment. There are also various steps in this method that are not properly standardized, and differences in, e.g., the length of the storage period in the dark, the irradiance at which sediments are exposed and the frequency and timing of sample inspection might influence quantitative estimates and hamper comparisons of the results of different studies. Nevertheless, the SDC-MPN method presents advantages over the direct examination of acid-cleaned sediment samples or the enumeration of resting spores in sediment trap samples, which do not allow discriminating resting from vegetative cells, nor viable from dead resting stages. In addition, the availability of mixed cultures of vegetative stages increases the chances for species identification, as compared to the examination of a limited number of resting stages that, at times, do not present clear distinctive features. A promising approach for a more complete characterization and quantification of the diversity of seed banks of unicellular organisms is represented by high throughput sequencing methods, which are based on the amplification of DNA environmental samples with universal or group-specific 
primers. These metagenomic analyses have been successfully applied to estimate diversity of eukaryotic lineages in coastal and deep sediments (e.g. Bik et al. 2012).

\section{Temporal patterns}

Peaks of individual diatom species in surface waters often corresponded to or preceded the peaks of abundance of resting stages in the sediment, demonstrating that sediments reflect by large the dynamics of planktonic populations. At times, however, no temporal match was detected. This lack of match could depend on several factors. Phytoplankton species distribution in coastal environments is constrained by advection and small-scale hydrodynamics and is characterized by high temporal and spatial variability; consequently, the weekly sampling frequency may have overlooked the highest cell densities of certain species in the water column. This might be true, for example, in the case of Chaetoceros socialis, where the high concentration of resting stages in November 2007 corresponded to moderate cell concentrations in the plankton.

The correspondence between the temporal dynamics of plankton blooms and spore assemblages probably reflects the combined effect of the rain of resting stages produced during - or at the end of - the bloom from the upper layers, and of the subsequent losses of those resting stages over time. The records of species in the sediments during or after peaks in surface waters might also relate to vegetative cells settling onto the bottom. However, sediment samples were stored in the dark and at low temperature at least $3 \mathrm{wk}$ prior to the first germination experiments. It is conceivable that all recently settled vegetative cells would either die or transform into resting stages during this time interval. While dominating the benthic assemblage during the vegetative bloom in the upper water column, resting stages of individual species could subsequently get partially buried by settling material or get mixed with the substrate by the bioturbation activity of benthic fauna or by the dredging activity of fishing nets; all of these factors could cause a decrease of their concentration in the sediments in an unpredictable fashion. In addition, the lack of a mandatory dormancy period in diatom spores (Hargraves \& French 1983) could allow them to germinate soon after their formation, without leaving a long-lasting fingerprint in the sediment. An alternative, or complementary, explanation for the temporal match between planktonic and benthic stages is that the germination potential of the latter is maximized in certain periods of the year, so that the germination timing contributes to produce repeated seasonal patterns of occurrence in the plankton. In this case, the maxima of resting stage viability of individual species would precede the bloom, which, however, was not assessable in this study due to the bi-monthly scale of the sediment sampling. On the other hand, the hypothesis of timed germination is not supported by the results of incubations of the same sample over time, which should have shown a marked decrease in viability for certain species after first germination and/or sudden peaks of viability months after sample collection, assuming that laboratory conditions did not affect germination patterns. Our results do not support the hypothesis of timed germination, but they cannot disprove it unequivocally either, considering the limitations and drawbacks of the methods applied.

\section{The resting strategy}

Our data suggest the presence of a gradient in the capability to rest and survive, i.e. to remain viable in the absence of light and at relatively low temperatures. Spore-forming species, such as most Chaetoceros or Leptocylindrus danicus, are examples of the 'classic' resting strategy, whereby their rather constant concentration in germination experiments repeated through time using the same sample indicates that they remain viable in the sediment for up to $1 \mathrm{yr}$ or more (Table 5, Fig. S1). The germination success of Skeletonema pseudocostatum markedly decreased over time for samples collected shortly after blooms, i.e. when they contained high numbers of recently settled cells, while the decrease was less dramatic in samples collected far away from bloom periods. This species is known to survive in anoxic sediment for decades (Härnström et al. 2011), and our results indicate either that its long-term survival is linked to anoxic conditions or that its life cycle includes both stages capable of long-term survival and stages with a limited survival capability. Several diatom species can survive dark conditions, probably forming resting cells, for time intervals spanning from a few to several weeks (e.g. Antia \& Cheng 1970, Smayda \& Mitchell-Innes 1974, Peters 1996a). Our results show that short-term dark survival is also evident in natural populations, as in the case of species that germinated from sediment only within a relatively short time period after their collection, such as Cylindrotheca closterium, Asterionellopsis glacialis, Thalas- 
sionema nitzschioides and Thalassiosira mediterranea (Table 5). The diversity of the resting capabilities of diatoms parallels those of dinoflagellates, in which morphologically and physiologically differentiated cysts with distinct, species-specific dormancy lengths have been reported along with pellicle cysts, which rather represent a short-term response to stressful environmental conditions (e.g. Bravo et al. 2010, Anderson et al. 2012). Diversity in the resting strategy is also shown by differences in the propensity to form spores, which is evident for several species when comparing the abundances of vegetative cells in the water column and the number of viable resting stages in the sediments. This ratio is high for Chaetoceros protuberans and C. diadema and even higher for $C$. socialis and C. curvisetus, all species for which resting spores are often recorded in the plankton of the area (D. Sarno unpubl. data). In contrast $C$. contortus and $C$. affinis reached relatively high concentrations in the water column but were seldom recorded in the sediment.

\section{The triggers of resting stage formation}

Resting stage formation has been related to nutrient deficiency at the end of bloom periods in the natural environment (e.g. Kuwata \& Takahashi 1990), while nutrient-depleted media are commonly used in the laboratory to obtain resting stages in diatom cultures (e.g. Kuwata et al. 1993, Sugie \& Kuma 2008). Our data also show a negative relationship between spore abundance and nutrient concentrations. The highest concentrations of diatom resting stages at our sampling station were recorded in sediment samples collected in late spring and summer, when several spore-forming Chaetoceros species, Skeletonema pseudocostatum and Leptocylindrus danicus reached their peak abundances. These late spring to summer peaks are related to the lateral transport of low salinity waters from the littoral area, with high nutrient loads that are rapidly exploited by phytoplankton (Zingone et al. 1990, Ribera d'Alcalà et al. 2004), leading to low DIN concentrations. It is difficult to distinguish in these cases between causal relationships and concomitant variations, but the latter seem more likely considering that other species in our study formed resting stages in periods when nutrients were not limiting. In addition, the relationship between nutrients and diatom resting stages is also affected by the low abundance of diatoms in the late autumn to winter months, when DIN values are higher (Ribera d'Alcalà et al. 2004).
The possible role of day length as an environmental trigger for germination of diatom resting stages and subsequent growth was postulated by Eilertsen et al. (1995). When sediments collected along the Norwegian coast were incubated at various irradiance and photocycle values, diatom growth was observed only when day length exceeded $11 \mathrm{~h}$ of light. We incubated sediments at day length conditions simulating those recorded at our latitude, with the aim of testing whether this hypothesis is also tenable for temperate species. The incubation protocol included a first week in which irradiance was extremely low $\left(\leq 5 \mu \mathrm{mol}\right.$ photons $\left.\mathrm{m}^{-2} \mathrm{~s}^{-1}\right)$ to simulate conditions met in the deeper layer of the water column, and a subsequent period at higher irradiance, presumably met when the germinated cells would reach more superficial surface layers. However, we could not detect a significant difference between the experimental conditions. Our results might have different explanations: (1) a day length threshold for germination could be an adaptation only in species or populations from high-latitude regions, where dark winter months constrain the growth of phototrophic species (Eilertsen \& Degerlund 2010); (2) the germination cue may be set by a combination of day length and temperature (McQuoid \& Hobson 1995); (3) the trigger for germination could be provided by a combination of day length and light quality/quantity; or (4) the dim light conditions at which we manipulated sediments and/or the irradiance values we used after the first week of incubation might have induced germination of all resting stages.

Laboratory experiments showed that a threshold irradiance is required for inducing germination and subsequent growth of diatom resting stages (e.g. Hollibaugh et al. 1981, Shikata et al. 2008), although germination of resting spores of Aulacoseira skvortzowii has also been observed in the dark (Jewson et al. 2008). Besides light quantity, light quality also seems to play a role, and it has recently been shown that both blue and red light wavelengths $(\geq 10 \mu \mathrm{mol}$ photons $\mathrm{m}^{-2} \mathrm{~s}^{-1}$ ) are effective in inducing the germination of Leptocylindrus danicus resting spores (Shikata et al. 2011). These wavelengths are perceived by photoreceptors - cryptochromes and phytochromes - in diatoms (Depauw et al. 2012). Selected wavelengths might thus represent signalling mechanisms for several biological processes, including germination of resting stages. Blue light penetrates to considerable depth, while red light is primarily absorbed within the first meters of the water column (Ragni \& Ribera D'Alcalà 2004). It follows that resting stages deposited on the shallower coastal 
belt can perceive light signals, while resuspension into the surface layers of the water column seems crucial for the recruitment of vegetative stages from deep seed banks. We are not aware of studies assessing in situ germination rates of diatom resting stages in the marine environment. Germination chambers deployed in the sediments (Ishikawa et al. 2007) might represent promising tools to investigate the dynamics of germination, assuming that careful manipulation of sediment samples is used to avoid exposure to light. Quantitative assessment of the recruitment rates in unicellular organisms is tricky because germinated cells only represent a minute fraction of the population in the water column (Ishikawa et al. 2007), and the concomitant vegetative growth masks the link between inoculum size and population development. In lakes, recruitment from the sediment and sinking to the sediment are higher under mixed conditions, while seasonal stratification of the water column acts as a 'cap' limiting both positive and negative migrations (Hansson 1995, 1996). The physical structure of the water column can thus affect the timing and extent of benthic-pelagic coupling, which will be maximal in periods of deep vertical mixing, when the highest abundances of resting-stage-forming Chaetoceros species and Skeletonema pseudocostatum are generally recorded (Ribera D'Alcalà et al. 2004, present study).

\section{Concluding remarks}

We investigated the temporal variability of speciesspecific diatom resting stage abundance in surface sediments of a coastal site in comparison with the abundances of vegetative stages in the plankton. While the match between the timing of planktonic cells and benthic stages emerged rather clearly from this study, the actual role of resting stages in seeding the blooms in the water column still remains puzzling. Germination of individual species appears to occur whenever sediments are exposed to light, and its success does not seem to be affected by changes in day length, thus failing to provide an explanation for species' seasonality in the plankton. This lack of a clear temporal connection from benthos to plankton points to the complex relationship between the 2 key phases of diatom species, but could also be due to the intrinsic limitations of the current methodologies used in the study of plankton and their resting stages. New integrated approaches are required, encompassing the exploration of more appropriate proce- dures to identify and quantify resting stages in the sediment, investigate their germination rates in the natural environment, and achieve a better appreciation of the small-scale physical processes governing resting stage transfer across the water column, e.g. re-suspension, seasonal and deep mixing (Raffaelli et al. 2003). Experimental studies to elucidate the cues that trigger shifts between actively growing vegetative cells and resting stages and vice versa and the molecular mechanisms through which diatoms perceive them are needed (von Dassow \& Montresor 2011). These research lines, empowered by new tools offered by current biotechnological and observational developments, should be pursued in order to define life-cycle traits (Litchman \& Klausmeier 2008) on which to build sound functional categories for planktonic species.

Acknowledgements. We thank the Management and Ecology of Coastal Areas Service and F. Tramontano for sampling at the LTER-MC station, G. Zazo and the Fishery Service for collecting the sediment samples, A. Passarelli for the analysis of chemical parameters, G. Lanzotti for preparing the figures, and C. Tortora for help with statistical analyses. This investigation was funded by the research project MIURVECTOR (vulnerabilità delle coste e degli ecosistemi marini italiani ai cambiamenti climatici e loro ruolo nei cicli del carbonio mediterraneo) and by Stazione Zoologica Anton Dohrn. The authors thank 2 anonymous reviewers for their constructive comments.

\section{LITERATURE CITED}

Anderson OR (1975) The ultrastructure and cytochemistry of resting cell formation in Amphora coffeaeformis (Bacillariophyceae). J Phycol 11:272-281

> Anderson OR (1976) Respiration and photosynthesis during resting cell formation in Amphora coffeaeformis (Ag.) Kütz. Limnol Oceanogr 21:452-456

Anderson DM, Alpermann TJ, Cembella AD, Collos Y, Masseret E, Montresor M (2012) The globally distributed genus Alexandrium: multifaceted roles in marine ecosystems and impacts on human health. Harmful Algae 14: 10-35

Antia NJ, Cheng JY (1970) The survival of axenic cultures of marine planktonic algae from prolonged exposure to darkness at $20^{\circ} \mathrm{C}$. Phycologia 9:179-184

Bik HM, Sung W, De Ley P, Baldwin JG, Sharma J, RochaOlivares A, Thomas WK (2012) Metagenetic community analysis of microbial eukaryotes illuminates biogeographic patterns in deep-sea and shallow water sediments. Mol Ecol 21:1048-1059

Borkman DG, Smayda T (2009) Multidecadal (1959-1997) changes in Skeletonema abundance and seasonal bloom patterns in Narragansett Bay, Rhode Island, USA. J Sea Res 61:84-94

> Bravo I, Figueroa RI, Garcés E, Fraga S, Massanet A (2010) The intricacies of dinoflagellate pellicle cysts: the example of Alexandrium minutum cysts from a bloom- 
recurrent area (Bay of Baiona, NW Spain). Deep-Sea Res II 57:166-174

- Chen CP, Sun L, Gao YH, Zhou QQ and others (2009) Seasonal changes of viable diatom resting stages in bottom sediments of Xiamen Bay, China. J Sea Res 61:125-132

Davis CO, Hollibaugh JT, Seibert DLR, Thomas WH, Harrison PJ (1980) Formation of resting spores by Leptocylindrus danicus (Bacillariophyceae) in a controlled experimental ecosystem. J Phycol 16:296-302

$>$ Depauw FA, Rogato A, Ribera d'Alcalà M, Falciatore A (2012) Exploring the molecular basis of response to light in marine diatoms. J Exp Bot 63:1575-1591

> Eilertsen HC, Degerlund M (2010) Phytoplankton and light during the northern high-latitude winter. J Plankton Res 32:899-912

Eilertsen HC, Sandberg S, Tøllefsen H (1995) Photoperiodic control of diatom spore growth: a theory to explain the onset of phytoplankton blooms. Mar Ecol Prog Ser 116: 303-307

$>$ French FW III, Hargraves PE (1985) Spore formation in the life cycles of the diatoms Chaetoceros diadema and Leptocylindrus danicus. J Phycol 21:477-483

> French FW III, Hargraves PE (1986) Population dynamics of the spore-forming diatom Leptocylindrus danicus in Narragansett Bay, Rhode Island. J Phycol 22:411-420

Fryxell GA (1983) Survival strategies of the algae. Cambridge University Press, Cambridge

> Garrison DL (1981) Monterey Bay phytoplankton. II. Resting spore cycles in coastal diatom populations. J Plankton Res 3:137-156

Garrison DL (1984) Planktonic diatoms. In: Steidinger KA, Walker LM (eds) Marine plankton life cycle strategies. CRC Press, Boca Raton, FL, p 1-17

Gran HH (1902) Das Plankton des norwegischen Nordmeeres von biologischen und hydrographischen Gesichtspunkten behandelt. Fiskeridir Skr Ser Havunders 2(III):1-222

Guillard RL, Ryther JH (1962) Studies of marine planktonic diatoms. I. Cyclotella nana Hustedt and Detonula confervacea (Cleve) Gran. Can J Microbiol 8:229-239

Hansen HP, Grasshoff K (1983) Automated chemical analysis. In: Grasshoff K, Ehrhardt M, Krernling K (eds) Methods of seawater analysis. Verlag Chemie, Weinheim, p 347-379

> Hansson LA (1995) Diurnal recruitment patterns in algae: effects of light cycles and stratified conditions. J Phycol 31:540-546

> Hansson LA (1996) Algal recruitment from lake sediments in relation to grazing, sinking, and dominance patterns in the phytoplankton community. Limnol Oceanogr 41: 1312-1323

Hargraves PE, French FW (1983) Diatom resting spores: significance and strategies. In: Fryxell GA (ed) Survival strategies of the algae. Cambridge University Press, Cambridge, p 49-68

> Härnström K, Ellegaard M, Andersen TJ, Godhe A (2011) Hundred years of genetic structure in a sediment revived diatom population. Proc Natl Acad Sci USA 108: $4252-4257$

Hasle GR, Syvertsen EE (1997) Marine diatoms. In: Tomas CR (ed) Identifying marine phytoplankton. Academic Press, San Diego, CA, p 5-385

Hensen V (1887) Über die Bestimmung des Planktons oder des im Meere treibenden Materials an Pflanzen und Tieren. 5. Bericht der Kommission zur wissenschaftlichen
Untersuchung der deutschen Meere in Kiel, 1882-1886, Jhg 12-16

Hollibaugh JT, Seibert DHL, Thomas WH (1981) Observations on the survival and germination of resting spores of three Chaetoceros (Bacillariophyceae) species. J Phycol 17:1-9

Holm-Hansen O, Lorenzen CJ, Holmes RW, Strickland JDH (1965) Fluorimetric determination of chlorophyll. J Cons Int Explor Mer 30:3-15

Imai I, Itoh K, Anraku M (1984) Extinction dilution method for enumeration of dormant cells of red tide organisms in marine sediments. Bull Plankton Soc Japan 31:123-124

Ishii Ki, Iwataki M, Matsuoka K, Imai I (2011) Proposal of identification criteria for resting spores of Chaetoceros species (Bacillariophyceae) from a temperate coastal sea. Phycologia 50:351-362

Ishikawa A, Furuya K (2004) The role of diatom resting stages in the onset of the spring bloom in the East China Sea. Mar Biol 145:633-639

Ishikawa A, Hattori M, Imai I (2007) Development of the 'plankton emergence trap/chamber (PET Chamber)', a new sampling device to collect in situ germinating cells from cysts of microalgae in surface sediments of coastal waters. Harmful Algae 6:301-307

Itakura S, Imai I, Itoh K (1997) 'Seed bank' of coastal planktonic diatoms in bottom sediments of Hiroshima Bay, Seto Inland Sea, Japan. Mar Biol 128:497-508

Jewson DH, Granin NG, Zhdanov AA, Gorbunova LA, Bondarenko NA, Gnatovsky RY (2008) Resting stages and ecology of the planktonic diatom Aulacoseira skvortzowii in Lake Baikal. Limnol Oceanogr 53:1125-1136

> Kuwata A, Takahashi M (1990) Life-form population responses of a marine planktonic diatom, Chaetoceros pseudocurvisetus, to oligotrophication in regionally upwelled waters. Mar Biol 107:503-512

> Kuwata A, Takahashi M (1999) Survival and recovery of resting spores and resting cells of the marine planktonic diatom Chaetoceros pseudocurvisetus under fluctuating nitrate conditions. Mar Biol 134:471-478

Kuwata A, Hama T, Takahashi M (1993) Ecophysiological characterization of two life forms, resting spores and resting cells, of a marine planktonic diatom, Chaetoceros pseudocurvisetus, formed under nutrient depletion. Mar Ecol Prog Ser 102:245-255

> Lelong A, Hégaret H, Soudant P, Bates SS (2012) Pseudonitzschia (Bacillariophyceae) species, domoic acid and amnesic shellfish poisoning: revisiting previous paradigms. Phycologia 51:168-216

> Lewis J, Harris ASD, Jones KJ, Edmonds RL (1999) Long term survival of marine planktonic diatoms and dinoflagellates in stored sediment samples. J Plankton Res 21: 343-354

Litchman E, Klausmeier CA (2008) Trait-based community ecology of phytoplankton. Annu Rev Ecol Evol Syst 39: 615-639

Marcus NH, Boero F (1998) The importance of benthicpelagic coupling and the forgotten role of life cycles in coastal aquatic systems. Limnol Oceanogr 43:763-768

- McQuoid MR (2002) Pelagic and benthic environmental controls on the spatial distribution of a viable diatom propagule bank on the Swedish west coast. J Phycol 38: 881-893

McQuoid MR, Godhe A (2004) Recruitment of coastal planktonic diatoms from benthic versus pelagic cells: varia- 
tions in bloom development and species composition. Limnol Oceanogr 49:1123-1133

McQuoid MR, Hobson LA (1995) Importance of resting stages in diatom seasonal succession. Eur J Phycol 31: 44-50

McQuoid MR, Hobson LA (1996) Diatom resting stages. Eur J Phycol 32:889-902

> McQuoid MR, Godhe A, Nordberg K (2002) Viability of phytoplankton resting stages in the sediments of a coastal Swedish fjord. Eur J Phycol 37:191-201

Murphy AM, Cowles TJ (1997) Effects of darkness on multiexcitation in vivo fluorescence and survival in a marine diatom. Limnol Oceanogr 42:1444-1453

Nanjappa D, Kooistra WHCF, Montresor M, Zingone A (2012) Revisiting the taxonomy of the genus Leptocylindrus Cleve (Bacillariophyceae) in the Gulf of Naples using morphological, molecular and physiological approaches. In: Sabbe K, Van de Vijver B, Vyverman W (eds) 22nd Int Diatom Symp. Abstracts VLIZ Spec Pub 58:197

Paul C, Barofsky A, Vidoudez C, Pohnert G (2009) Diatom exudates influence metabolism and cell growth of cocultured diatom species. Mar Ecol Prog Ser 389:61-70

Peters E (1996a) Prolonged darkness and diatom mortality. II. Marine temperate species. J Exp Mar Biol Ecol 207: 43-58

Peters E (1996b) Prolonged darkness and diatom mortality. I. Marine Antarctic species. J Exp Biol 207:24-41

Pitcher GC (1986) Sedimentary flux and the formation of resting spores of selected Chaetoceros species at two sites in the southern Benguela system. S Afr J Mar Sci 4: 231-244

> Pitcher GC (1990) Phytoplankton seed populations of the Cape Peninsula upwelling plume, with particular reference to resting spores of Chaetoceros (Bacillariophyceae) and their role in seeding upwelling waters. Estuar Coast Shelf Sci 31:283-301

Pitcher GC, Walker DR, Mitchell-Innes BA, Moloney CL (1991) Short-term variability during an anchor station study in the southern Benguela upwelling system: phytoplankton dynamics. Prog Oceanogr 28:39-64

Raffaelli D, Bell E, Weithoff G, Matsumoto A and others (2003) The ups and downs of benthic ecology: considerations of scale, heterogeneity and surveillance for benthic-pelagic coupling. J Exp Mar Biol Ecol 285-286: 191-203

Ragni M, Ribera D'Alcalà M (2004) Light as an information carrier underwater. J Plankton Res 26:433-443

Ribera d'Alcalà M, Conversano F, Corato F, Licandro $\mathrm{P}$ and others (2004) Seasonal patterns in plankton communities in a pluriannual time series at a coastal Mediterranean site (Gulf of Naples): an attempt to discern recurrences and trends. Sci Mar 68(Suppl 1):65-83

Rines JEB, Hargraves PE (1988) The Chaetoceros Ehrenberg (Bacillariophyceae) flora of Narragansett Bay, Rhode Island, USA. Bibliotheca Phycologica, Band 79, J. Cramer, Berlin

Editorial responsibility: Katherine Richardson, Copenhagen, Denmark
Round FE, Crawford RM, Mann DG (1990) The diatoms. Biology and morphology of the genera. Cambridge University Press, Cambridge

Shikata T, Nagasoe S, Matsubara T, Yoshikawa S and others (2008) Factors influencing the initiation of blooms of the raphidophyte Heterosigma akashiwo and the diatom Skeletonema costatum in a port in Japan. Limnol Oceanogr 53:2503-2518

Shikata T, Nukata A, Yoshikawa S, Matsubara T and others (2009) Effects of light quality on initiation and development of meroplanktonic diatom blooms in a eutrophic shallow sea. Mar Biol 156:875-889

Shikata T, Iseki M, Matsunaga S, Higashi Si, Kamei Y, Watanabe $M$ (2011) Blue and red light-induced germination of resting spores in the red-tide diatom Leptocylindrus danicus. Photochem Photobiol 87:590-597

- Smayda TJ, Mitchell-Innes B (1974) Dark survival of autotrophic, planktonic marine diatoms. Mar Biol 25: 195-202

> Smetacek VS (1985) Role of sinking in diatom life-history cycles: ecological, evolutionary and geological significance. Mar Biol 84:239-251

> Sugie K, Kuma K (2008) Resting spore formation in the marine diatom Thalassiosira nordenskioeldii under ironand nitrogen-limited conditions. J Plankton Res 30: 1245-1255

Syvertsen EE (1979) Resting spore formation in clonal cultures of Thalassiosira antarctica Comber, T. nordenskioeldii Cleve and Detonula confervacea (Cleve) Gran. Nova Hedwigia Beih 64:41-63

Thompson PA, Bonham PI, Swadling KM (2008) Phytoplankton blooms in the Huon Estuary, Tasmania: top-down or bottom-up control? J Plankton Res 30:735-753

Throndsen J (1978) The dilution culture method. In: Sournia A (ed) Phytoplankton manual. UNESCO Monographs on Methodology, Paris, p 218-224

Utermöhl H (1958) Zur Vervollkommnung der quantitativen Phytoplankton-Methodik. Mitt Internat Verein Theor Angew Limnol 9:1-38

> von Dassow P, Montresor M (2011) Unveiling the mysteries of phytoplankton life cycles: patterns and opportunities behind complexity. J Plankton Res 33:3-12

> von Stosch HA, Theil G, Kowallik K (1973) Entwicklungsgeschichtliche Untersuchungen an zentrischen Diatomeen. V. Bau und Lebenszyklus von Chaetoceros didymum, mit Beobachtungen über einige andere Arten der Gattung. Helgol Wiss Meeresunters 25:384-445

> Zingone A, Montresor M, Marino D (1990) Summer phytoplankton physiognomy in coastal water of the Gulf of Naples. PSZNI: Mar Ecol 11:157-172

Zingone A, Casotti R, Ribera d'Alcalà M, Scardi M, Marino D (1995) 'St Martin's Summer': the case of an autumn phytoplankton bloom in the Gulf of Naples (Mediterranean Sea). J Plankton Res 17:575-593

Zingone A, Dubroca L, Iudicone D, Margiotta F and others (2010) Coastal phytoplankton do not rest in winter. Estuar Coast 33:342-361

Submitted: June 11, 2012; Accepted: December 27, 2012 Proofs received from author(s): May 20, 2013 